\title{
Estimasi Perubahan lahan Sawah dengan Klasifikasi Tidak Terbimbing Citra MODIS EVI DI PROVINSI JAWA BARAT
}

Unsupervised Classification of MODIS EVI to Estimate Paddy Field Change in West Java, Indonesia

\author{
Rizky Mulya Sampurno"), Anas Bunyamin²), Totok Herwanto') \\ ${ }^{1)}$ Departemen Teknik Pertanian dan Biosistem, Universitas Padjadjaran \\ ${ }^{2)}$ Departemen Teknologi Industri Pertanian, Universitas Padjadjaran \\ Jl. Raya Bandung Sumedang KM 21, Jatinangor 40600 \\ Email: rizky.mulya@unpad.ac.id
}

\begin{abstract}
ABSTRAK
Berdasarkan data statistik, sejak tahun 2008 hingga saat ini luas sawah di Provinsi Jawa Barat cenderung mengalami penurunan. Hal ini mendorong dibutuhkannya informasi yang cepat dan tepat terkait lokasi dan luas lahan sawah untuk menjaga ketahanan pangan nasional. Teknologi penginderaan jauh telah menjadi alat bantu yang handal dalam memecahkan masalah ini. Melalui klasifikasi citra satelit penginderaan jauh, luas lahan sawah dapat diketahui dengan mudah. Tujuan dari penelitian ini adalah melakukan klasifikasi citra MODIS EVI 250 m untuk memetakan lahan sawah serta memperkirakan luas dan sebaran perubahan lahan sawah di Provinsi Jawa Barat. Metode klasifikasi yang digunakan adalah klasifikasi tidak terbimbing ISODATA dengan jumlah kelas klasifikasi ditentukan melalui analisis divergensi pada citra komposit yang dianalisis. Pemilihan kelas sawah dilakukan melalui pengecekan pola spektral pada piksel-piksel citra yang telah diklasifikasi. Menurut pemantauan MODIS EVI 250 m, luas sawah di Jawa Barat mengalami penurunan sebesar 17.35\% selama kurun waktu 10 tahun dari 1,189,728.85 ha pada tahun 2006 menjadi 983,342.77 ha pada tahun 2016 . Penurunan luas lahan sawah diduga disebabkan oleh perubahan lahan sawah ke bukan sawah. Terdapat perbedaan luas sawah antara data BPS dengan citra MODIS yang disebabkan oleh metode yang berbeda, namun keduanya menunjukkan kecenderungan total luas sawah yang menurun. Berdasarkan hasil tersebut, citra MODIS dapat dimanfaatkan dalam memperkirakan perubahan lahan serta dapat dijadikan pendukung dalam pengambilan keputusan.
\end{abstract}

Kata kunci: klasifikasi tidak terbimbing, ISODATA, MODIS, EVI, luas sawah

\begin{abstract}
Since 2008, paddy field area in West Java province has decreased. That condition needs paddy field information correctly and accurately to support national food security. Remote sensing technology has powerful tool to solve that problem. Paddy field area can be estimated easily trough classification of remote sensing image data. This paper aims to explain about unsupervised classification of MODIS EVI $250 \mathrm{~m}$ as well as to estimate paddy field change area in West Java. ISODATA has used for classification. Amount of classes determined though divergence statistics of the composite analyzed image. Then, the next process was selection classes these belong to paddy field by identify spectral pattern like paddy. The result showed that total paddy area in West Java has decreased about 17.35\% from 2006 to 2016, 1,189,728.85 ha to 983,342.77 ha, respectively. The losses area was estimated due to land use change from paddy to other utilization. Total paddy field area by MODIS was bigger than statistic data. It was due to different method in data acquisition. Classification of MODIS image can provide useful information both amount and location regarding paddy field change; it can be used to support decision making.
\end{abstract}

Keywords: unsupervised classification, ISODATA, MODIS, EVI, paddy field area

Diterima : 1 Agustus 2017 ; Disetujui : 25 September 2017; Online Published : 26 Oktober 2017

DOI : 10.24198/jt.vol11n2.6

Estimasi Perubahan Lahan Sawah dengan Klasifikasi Tidak Terbimbing Citra MODIS EVI di Provinsi Jawa 


\section{PENDAHULUAN}

Klasifikasi tidak terbimbing biasanya dimanfaatkan pada proses klasifikasi citra satelit untuk memetakan tutupan lahan pada area yang belum dikenali sebelumnya. Hal ini disebabkan karena data lapang tidak cukup tersedia (Jansen dan Gorte, 2001). Berbeda dengan klasifikasi terbimbing, data lapang dibutuhkan sebagai acuan dalam menentukan kelas tutupan lahan (Sampurno dan Thoriq, 2016). Pengambilan data lapang untuk kawasan regional cukup sering terkendala oleh waktu dan biaya karena wilayah yang sangat luas serta heterogenitas yang tinggi. Menurut Jaya (2010) klasifikasi tidak terbimbing dapat digunakan untuk kawasan regional. Metode klasifikasi yang sering digunakan diantaranya adalah ISODATA dan $k$-mean clustering.

Saat ini citra satelit MODIS dinilai handal dalam pemantauan tutupan lahan. Kehandalan ini terletak pada resolusi temporal yang cukup baik yakni memantau objek di permukaan bumi pada lokasi yang sama dengan periode ulang 16 harian. Walaupun resolusi spasialnya cukup kasar, hal ini tidak menghalangi kajian tutupan lahan, bahkan keakurasian pemantauan dapat ditingkatkan dengan menggabungkannya dengan citra satelit beresolusi lebih besar. Selain itu untuk kajian kawasan secara regional, satelit MODIS menjadi andalan para peneliti. Misalnya dinamika vegetasi secara regional (Setiawan et al, 2011), perubahan lahan (Setiawan dan Yoshino, 2014), monitoring lahan pertanian (Noer, 2008; Semedi, 2012), hingga pemberantasan gulma (Sampurno et al, 2014).

Penelitian ini menggunakan citra satelit MODIS yang dimanfaatkan untuk memetakan lahan sawah di Provinsi Jawa Barat. Provinsi Jawa Barat merupakan salah satu daerah penghasil padi di Indonesia (PUSDATIN, 2015), namun dengan berkembangnya perekonomian, pendidikan, wisata, dan kuliner telah menyebabkan terjadinya perubahan lahan sawah menjadi non sawah. Hal ini berdampak pada penurunan luas dan produktifitas sawah yang berimbas pada akan melemahnya ketahanan pangan. Menurut Arsyad A. dan Rustiadi (2008), sejak 1999 Jawa Barat merupakan provinsi di pulau Jawa yang mengalami penurunan lahan hingga 0.199 juta ha. Octora (2014) melaporkan bahwa berdasarkan pantauan citra MODIS $500 \mathrm{~m}$, luas sawah mengalami penurunan dari tahun 2008 hingga 2012 dari 1,640,600 ha menjadi 918,100 ha. Hal ini sejalan dengan data BPS, luas sawah tahun 2008 hingga 2014 terus menerus menurun tiap tahunnya (BPS, 2015, 2013, 2011, 2009). Tujuan dari penelitian ini adalah melakukan klasifikasi tidak terbimbing citra MODIS EVI 250 m untuk memetakan lahan sawah serta memperkirakan luas serta sebaran perubahan lahan sawah di Provinsi Jawa Barat.

\section{METODOLOGI PENELITIAN}

\section{Lokasi Penelitian}

Wilayah penelitian adalah Provinsi Jawa Barat, Indonesia yang terletak di pulau Jawa (106²2' 13.8' BT - 108 ${ }^{\circ} 50^{\prime} 1.8^{\prime \prime}$ BT; 5⒌ $54^{\prime} 49.6^{\prime \prime}$ LS - 749'15.5" LS) dengan luas wilayah

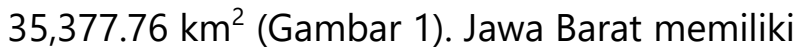
27 kabupaten/kota. Menurut BPS (2016), 26.08\% wilayah Jawa Barat adalah lahan sawah terdiri dari sawah irigasi dan tadah hujan, 50.98\% adalah lahan bukan sawah dan 22.94\% sisanya adalah lahan bukan pertanian. Sedangkan berdasarkan PUSDATIN (2015), Jawa Barat merupakan provinsi dengan luas sawah terbesar ketiga setelah Provinsi Jawa Timur dan Provinsi Jawa Tengah. Oleh karena itu Jawa Barat memiliki peran penting dalam memenuhi ketersediaan pangan di Indonesia. 


\section{Pulau Jawa, Indonesia}

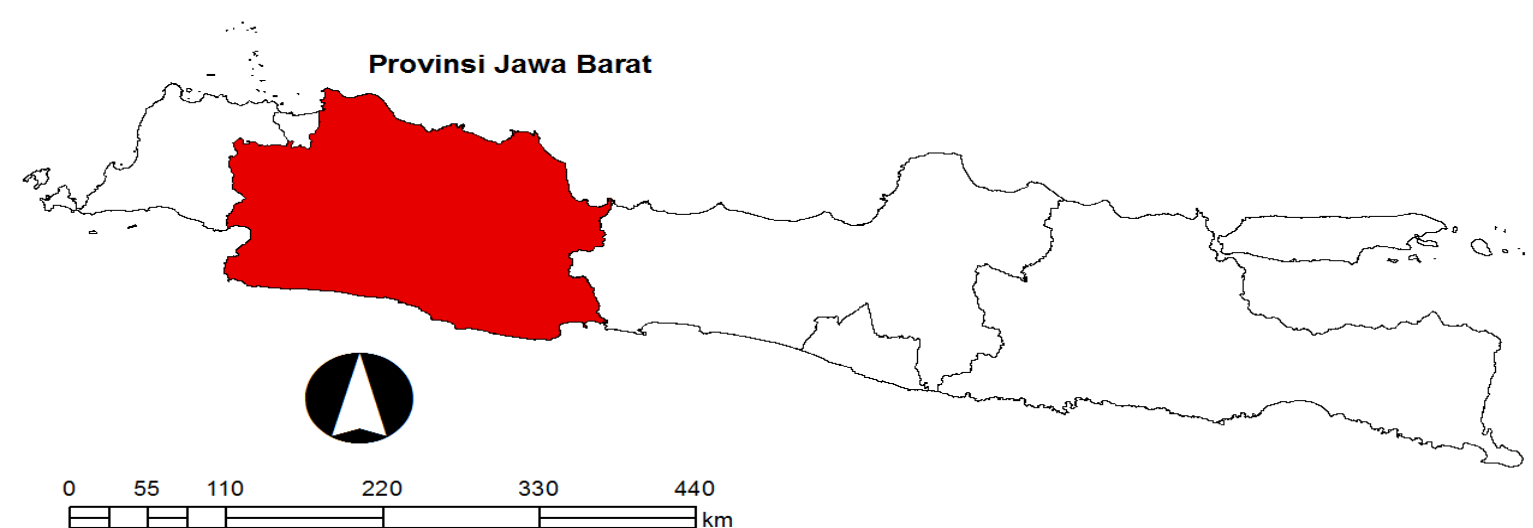

Gambar 1. Wilayah penelitian

\section{Data Citra Satelit}

Data citra MODIS yang digunakan adalah MOD13Q1 Enhanced Vegetation Index (EVI); resolusi temporal 16 hari; resolusi spasial 250 m. Data tersebut telah terkoreksi secara sistematis dari pengaruh gas dan sebaran aerosol. EVI diperoleh dari persamaan (1). Model EVI tersebut dikembangkan dengan tujuan untuk mengoptimalkan sinyal vegetasi yang lebih sensitif terhadap wilayah yang memiliki kerapatan biomas tinggi. EVI juga telah meminimalkan pengaruh atmosfer/aerosol resistance menggunakan band biru untuk mengkoreksi pengaruh aerosol pada band merah (Huete et al., 1997).

$$
E V I=G \frac{\rho_{\text {nir }}^{*}-\rho_{\text {red }}^{*}}{\rho_{\text {nir }}^{*}+C_{1} \rho_{\text {red }}^{*}-C_{2} \rho_{\text {blue }}^{*}+L}(1+L)
$$

keterangan, $\rho_{\text {nir, }}^{*} \rho_{\text {red }}^{*}$ dan $\rho_{\text {blue }}^{*}$ masingmasing adalah reflektansi penginderaan jauh pada band near-infrared, merah dan biru, $L$ adalah faktor penyesuaian tanah, $C_{1}$ dan $C_{2}$ menjelaskan penggunaan band biru yang mengkoreksi band merah untuk sebaran aerosol atmosfer. Secara empiris, koofisien $C_{1}$, $C_{2}$ dan $L$, masing-masing adalah 6.0, 7.5 and
1.0, G adalah gain faktor sebesar 2.5 (Huete et al., 1997).

Penelitian ini menggunakan data MODIS EVI tahun 2005, 2006, 2015, dan 2016. Data yang digunakan merupakan data hasil perekaman setiap 16 hari selama bulan Januari - Desember pada setiap tahunnya. Sehingga citra yang terkumpul setiap tahun terdiri dari 23 citra. Data tersebut tersedia pada Land Processes Distributed Active Archive Center (LP DAAC) (http://lpdaac.usgs.gov) atau Warehouse Inventory Search Tool (WIST) (https://wist.echo.nasa.gov) tile h28v09.

Selanjutnya data MODIS EVI diekstrak dari MOD13Q1 menggunakan MODIS Reprojection Tool (2017) kemudian disimpan ke dalam format GeoTIFF dengan koordinat Geographic pada datum World Geodetics System (WGS) 1984. Data MODIS EVI disusun secara berurutan untuk menghasilkan data time-series (layer stacking) kemudian dipotong (clip) berdasarkan batas administrasi Provinsi Jawa Barat. Data time-series yang di buat adalah EVI 2005-2006 dan EVI 2015-2016, masing-masing teridiri dari 46 layer. Citra hasil penyusunan berurutan (stacked image) disebut sebagai citra komposit ditunjukkan pada Gambar 2. 


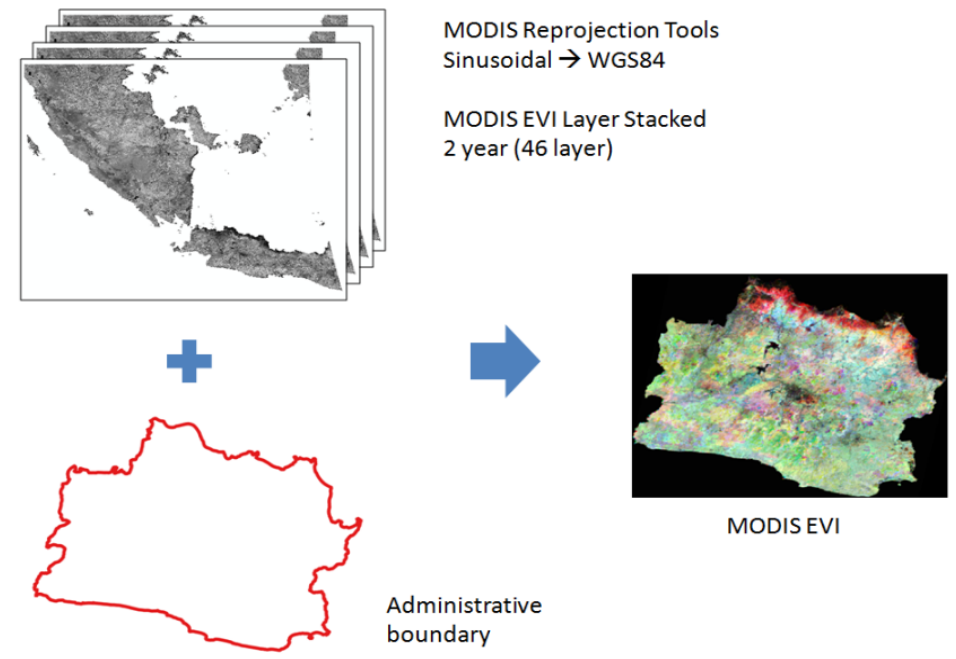

Gambar 2. Hasil penyusunan berurutan dan pemotongan citra MODIS EVI

\section{Data Koordinat Sawah}

Sejumlah data berupa titik koordinat sawah dijadikan sebagai acuan dalam menentukan kelas dan validasi tutupan lahan. Data tersebut dikumpulkan dari penelitian terdahulu dan dari interpretasi secara visual citra google maps (https://www.google.com/maps). Hasil interpretasi google maps diasumsikan sebagai kondisi tutupan lahan saat ini. Citra google map memiliki resolusi sedang hingga tinggi yang diperoleh dari berbagai satelit seperti Landsat, Wordview, Quickbird dan Ikonos. Data titik koordinat yang terkumpul yaitu 14 titik sawah tahun 2007 (Noer, 2008), 13 titik sawah tahun 2012 (Octora, 2014), 10 titik sawah hasil survei lapang tahun 2017, serta 278 titik sawah dari google map tahun 2017 (Gambar 3).

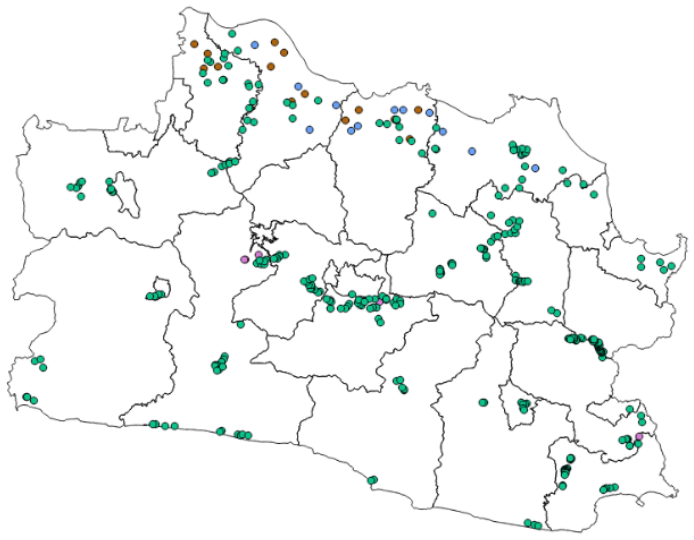

Gambar 3. Sebaran titik koordinat sawah

Menurut Jaya (2010), jumlah kelas yang akan dibuat sebaiknya lebih besar dari jumlah kelas tutupan yang mungkin atau yang ingin dibuat pada citra, namun, Amjad (2009) dan Semedi (2012) menggunakan analisis statistik divergensi dalam menentukan jumlah kelas yang optimal untuk klasifikasi. Statistik divergensi dinyatakan dalam nilai separability/keterpisahan. Nilai average separability adalah kesamaan antara dua kelas yang paling mirip, sedangkan minimum separability adalah kesamaan diantara semua kelas. Oleh karena itu, kedua nilai tersebut harus dipilih yang paling besar. Selanjutnya 
citra diklasifikasi dengan ISODATA pada jumlah kelas 10 - 50 dengan nilai batas ambang konvergensi 0.950 dan iterasi maksimum adalah 50 kemudian dipilih jumlah kelas yang optimal untuk klasifikasi.

\section{Deteksi Lahan Sawah}

Lahan sawah ditentukan dari kelas-kelas dalam citra hasil klasifikasi yang memiliki karakteristik spektral yang menyerupai pola temporal EVI tanaman padi. Pola temporal EVI tanaman padi dapat menggambarkan siklus pertumbuhan dan perkembangan tanam padi dari awal tanam hingga panen. Satu siklus pertumbuhan tanaman padi ditandai dengan meningkatnya dan menurunnya nilai EVI, masing-masing merupakan fase vegetatif dan fase generatif tanaman padi Berbeda dengan pola temporal objek lainnya seperti hutan, badan air dan area terbangun, padi/sawah memiliki karakteristik unik berupa pola nilai EVI turun naik pada setiap siklus dalam rentang waktu yang relatif sama pada setiap tahunnya (Tabel 1 No. 1). Karakteristik ini dijadikan pedoman dalam mengelompokkan suatu kelas tutupan lahan ke dalam kelas sawah. Pola temporal EVI juga dianggap handal dalam memberikan informasi mengenai pola dinamika (Setiawan et al., 2016), jumlah pola tanam tanaman padi dalam setahun (Setiawan et al., 2013), serta monitoring perubahan lahan (Permatasari et al., 2016).

Tabel 1. Contoh pola temporal EVI selama 2 tahun

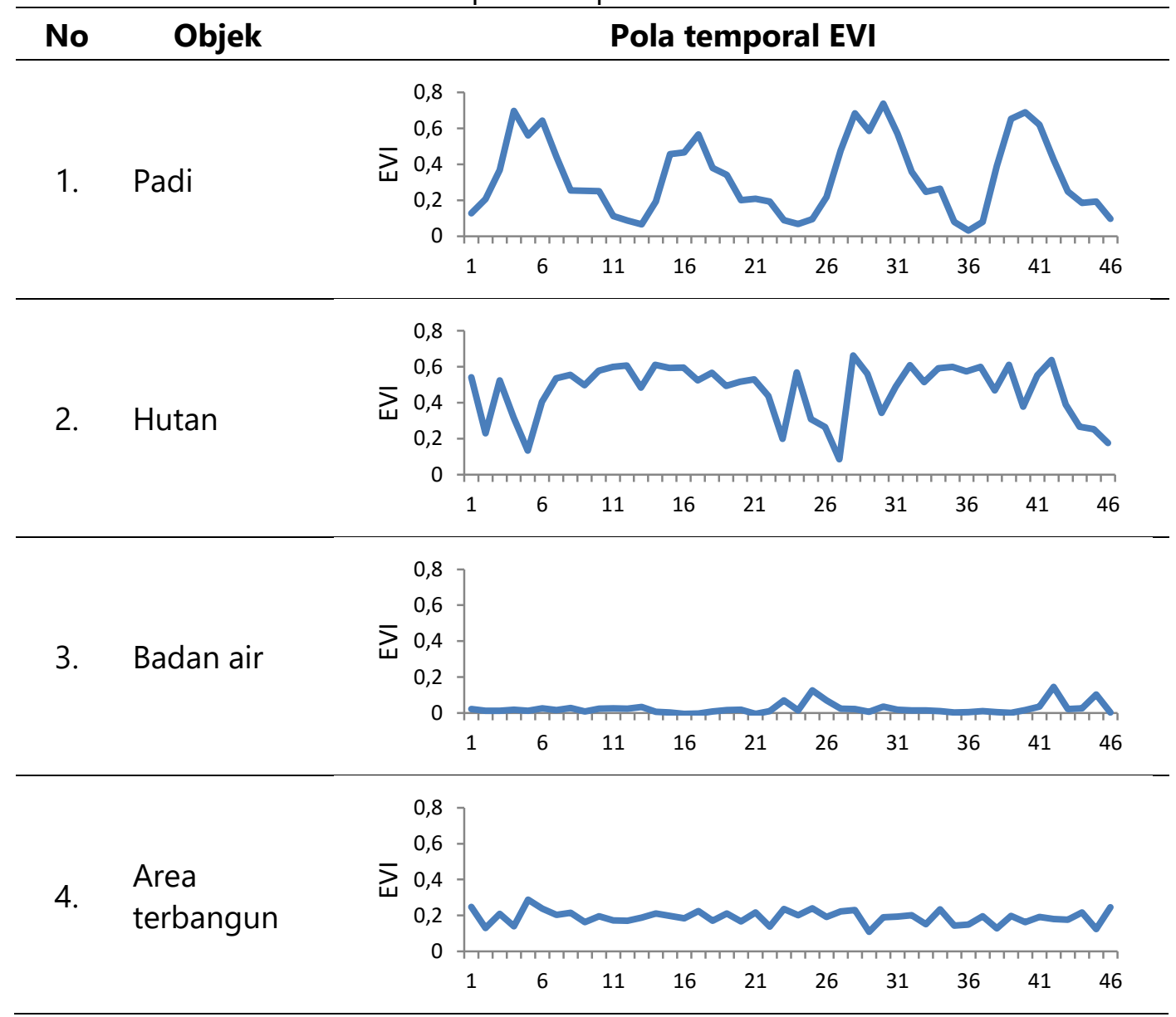


Data spasial yang dihasilkan dari klasifikasi tak terbimbing adalah kelas tutupan lahan berdasarkan nilai EVI. Kelas tutupan lahan selanjutnya dikelompokkan ke dalam 2 kelas yaitu sawah dan bukan sawah. Kelas sawah diperoleh dari hasil pemeriksaan pola spektral pada masing-masing kelas tutupan lahan. Kelas sawah yang dipilih merupakan kelas yang memiliki pola spektral mirip dengan pola temporal pertumbuhan tanaman padi. Data titik koordinat sawah digunakan sebagai acuan dalam menentukan kelas.

\section{Analisis Data}

Analisis data dilakukan untuk memperkirakan lokasi, jumlah dan laju penyusutan atau pertumbuhan luas lahan sawah di Jawa Barat antara tahun 2005-2006 dan 2015-2016. Laju penyusutan atau pertumbuhan dihitung dengan menggunakan persamaan (2).

Laju Penyusutan atau Pertumbuhan =

$$
\left(\frac{\mathrm{LS}_{2016}-\mathrm{LS}_{2006}}{\mathrm{LS}_{2006}}\right) \times 100 \%
$$

dimana $\mathrm{LS}_{2016}$ adalah luas sawah hasil klasifikasi citra MODIS EVI tahun 2015-2016, dan LS $_{2006}$ adalah luas sawah hasil klasifikasi citra MODIS EVI tahun 2005-2006.

Selanjutnya luas lahan sawah di Provinsi Jawa Barat tahun 2005-2006 dan tahun 20152016 hasil klasifikasi citra MODIS EVI dibandingkan dengan data statistik pertanian dari BPS untuk mengetahui seberapa besar perbedaan antara hasil klasifikasi citra MODIS EVI serta tren penyusutan atau pertumbuhan yang terjadi. Data statistik yang digunakan adalah rata-rata luas lahan sawah tahun 20052006 dan rata-rata luas sawah tahun 20152016.

\section{HASIL DAN PEMBAHASAN \\ Klasifikasi Citra MODIS EVI}

Citra MODIS EVI tahun 2005 - 2006 disusun berurut menjadi sebuah citra komposit EVI 2006 yang terdiri dari 46 layer. Hal yang sama dilakukan pada citra MODIS EVI tahun 2015 - 2016 menghasilkan citra komposit EVI 2016. Kedua citra komposit tersebut di klasifikasi menggunakan metode ISODATA ke dalam kelas tutupan lahan yang telah ditentukan sebelumnya. Jumlah kelas tutupan lahan yang optimal diperoleh dari analisis statistik divergensi hasil klasifikasi ISODATA untuk jumlah kelas $10-50$.

Berdasarkan statistik divergensi jumlah kelas yang optimal untuk citra EVI 2006 adalah 47 kelas (Gambar 4) dan citra EVI 2016 adalah 46 kelas. Kelas optimal yang diperoleh merupakan nilai maksimum hasil penjumlahan antara average separability dan minimum separability.

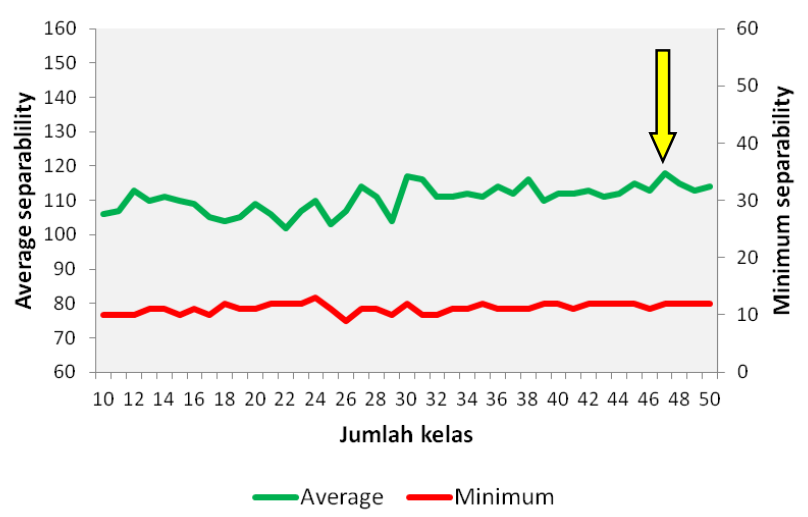

Gambar 4. Statistik divergensi (Average dan Minimum) untuk mengidentifikasi jumlah kelas yang optimal citra EVI 2006 


\section{Luas Lahan Sawah di Jawa Barat menurut Citra MODIS}

Luas lahan sawah di Provinsi Jawa Barat berdasarkan citra MODIS pada tahun 2006 adalah 1,189,729 ha dan tahun 2016 adalah $983,342.8$ ha. Hasil tersebut menunjukkan bahwa luas sawah di Jawa Barat mengalami penurunan sebesar $17.35 \%$. Hal ini sejalan dengan temuan Octora (2014), berdasarkan citra MODIS EVI 500 m luas sawah pada tahun 2008 hingga 2012 telah mengalami penurunan walaupun menggunakan metode klasifikasi yang berbeda. Penurunan yang terjadi tidak dapat diketahui dengan tepat penyebabnya karena tidak dilakukan cek lapangan hasil klasifikasi citra MODIS secara detail dan menyeluruh. Namun penurunan luas sawah yang terjadi kemungkinan adanya alih fungsi lahan dari lahan sawah ke pertanian non sawah atau lahan sawah ke lahan bukan pertanian.

Setiawan dan Yoshino (2014) dengan menggunakan MODIS EVI 250 m, pada tahun 2006 - 2007 di pulau Jawa telah terjadi perubahan lahan dari padi sawah irigasi dengan 2 kali musim panen menjadi pemukiman, pertanian dataran tinggi menjadi pemukiman, semak-semak di dataran tinggi menjadi pertanian intensif, lahan kering dataran tinggi menjadi menjadi rumput dan semak, pertanian intensif di dataran tinggi menjadi lahan kering.

Secara visual pada Gambar 5 dapat dilihat distribusi spasial perbedaan lahan sawah tahun 2006 dengan tahun 2016. Perbedaan cukup jelas terdapat pada bagian utara dan tengah wilayah Jawa Barat. Perbedaan tersebut dapat disebabkan oleh perubahan dari lahan sawah ke bukan sawah atau perubahan dari non sawah ke sawah. Selain itu, faktor iklim juga dapat mempengaruhi perubahan lahan dari sawah ke non sawah. Bahar (2012) telah memodelkan adanya penurunan produktifitas tanaman padi di Provinsi Jawa Barat selama tahun 2004 - 2008 yang dipengaruhi perubahan iklim diantaranya suhu, curah hujan, radiasi dan angin. Selang waktu pemodelan tersebut bersamaan dengan adanya fenomena El-Nino (2004-2006) dan La-Nina (2007-2008). Berdasarkan hasil pemodelan, produktivitas padi menurun secara konstan sebesar 0.6 ton/ha. Hal ini mendorong petani lebih memilih menanam tanaman lain yang lebih menguntungkan atau memanfaatkan lahannya pada sektor perekonomian.
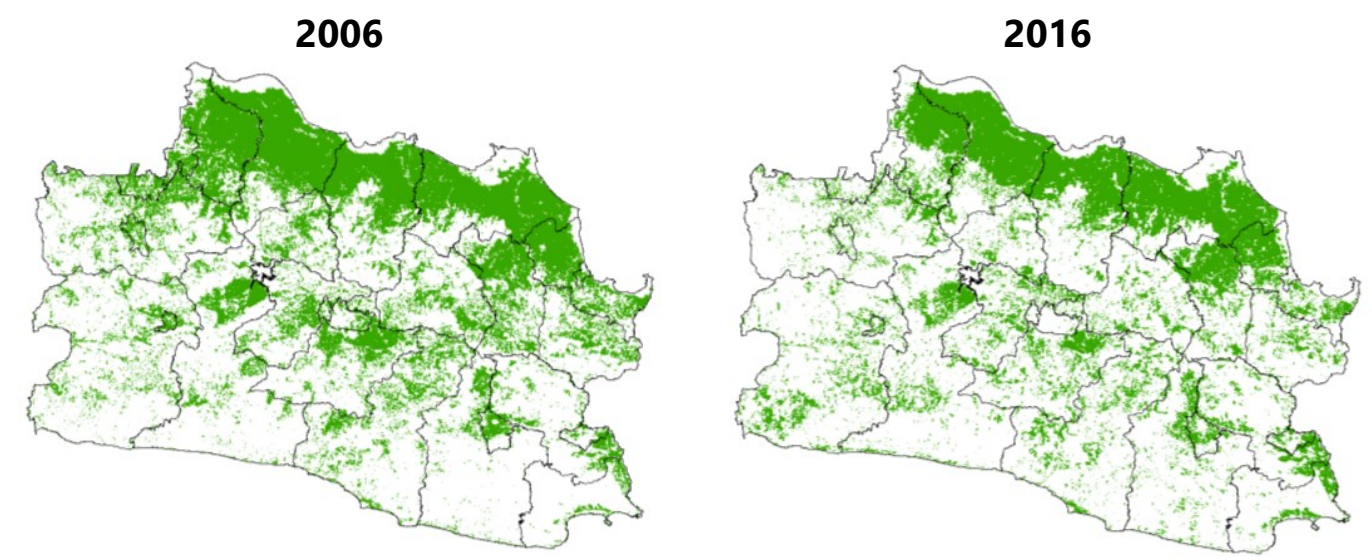

Gambar 5. Distribusi spasial sawah di Provinsi Jawa Barat berdasarkan Citra MODIS EVI 2006 dan 2016 


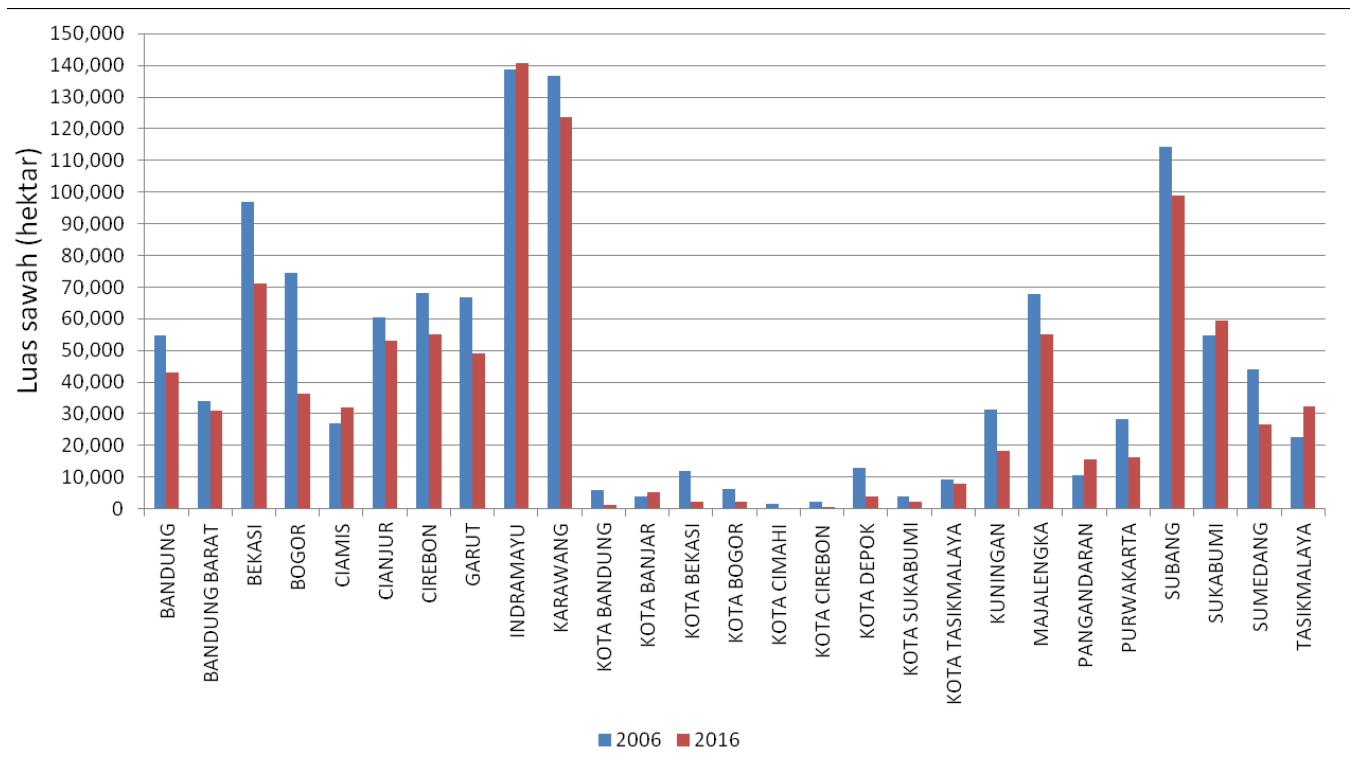

Gambar 6. Perbandingan luas sawah kabupaten/kota di Provinsi Jawa Barat berdasarkan citra MODIS tahun 2006 dengan tahun 2016

Perbandingan luas sawah per kabupaten/kota antara tahun 2006 dengan tahun 2016 berdasarkan citra MODIS ditunjukkan pada Gambar 6. Kabupaten Indramayu merupakan kabupaten yang memiliki luas sawah terbesar di Provinsi Jawa Barat. Hal ini sejalan dengan data BPS (2016). Bila dibandingkan dengan luas total sawah tahun 2016 berdasarkan citra MODIS, sebanyak 14.32\% lahan sawah di Provinsi Jawa Barat berada di Indramayu. Kabupaten Karawang dan Subang berada di peringkat dua dan tiga kabupaten dengan luas sawah terbesar. Selain penurunan luas sawah, beberapa kabupaten/kota mengalami peningkatan luas sawah diantaranya Kabupaten Ciamis, Kabupaten Indramayu, Kota Banjar, Kabupaten Pangandaran, Kabupaten Sukabumi dan Kabupaten Tasikmalaya. Peningkatan luas sawah ini merupakan hasil analisis citra MODIS dan perlu dilakukan cek lapangan lebih lanjut untuk memastikan lokasi dan luas area sawah yang bertambah.

Secara umum kabupaten/kota di Provinsi Jawa Barat mengalami penurunan luas lahan sawah. Tabel 2 menunjukkan luas penyusutan lahan sawah di setiap kabupaten/kota. Penyusutan lahan sawah terbesar terjadi di Kabupaten Bogor dan terbesar kedua adalah Kabupaten Bekasi. Kedua kabupaten ini merupakan wilayah penyangga ibu kota negara sehingga dapat diperkirakan bahwa penyusutan lahan sawah terjadi akibat pembangunan sektor industri jasa dan pemukiman. Dalam kurun waktu 10 tahun, Kabupaten Bogor kehilangan lebih dari setengah lahan sawah dan Bekasi kehilangan lebih dari $25 \%$ lahan sawah. 
Tabel 2. Penyusutan/penambahan luas lahan sawah per kabupaten/kota di Provinsi Jawa Barat berdasarkan citra MODIS tahun 2006 dan 2016.

\begin{tabular}{|c|c|c|c|c|c|}
\hline \multirow{2}{*}{ No } & \multirow{2}{*}{ Kab/Kota } & \multicolumn{2}{|c|}{ Tahun } & \multirow{2}{*}{$\begin{array}{c}\text { Penyusutan/ } \\
\text { penambahan luas (\%) }\end{array}$} & \multirow{2}{*}{$\begin{array}{c}\text { Laju penyusutan/ } \\
\text { penambahan terhadap } \\
\text { luas sawah total }\end{array}$} \\
\hline & & 2006 & 2016 & & \\
\hline 1 & BANDUNG & 54890.7 & 43046.5 & -21.58 & -1.00 \\
\hline 2 & BANDUNG BARAT & 33990.3 & 31095.7 & -8.52 & -0.24 \\
\hline 3 & BEKASI & 96896.4 & 71092.9 & -26.63 & -2.17 \\
\hline 4 & BOGOR & 74571.1 & 36321.5 & -51.29 & -3.21 \\
\hline 5 & CIAMIS & 26897.7 & 31887.8 & 18.55 & 0.42 \\
\hline 6 & CIANJUR & 60574.4 & 53030.1 & -12.45 & -0.63 \\
\hline 7 & CIREBON & 68018.7 & 55032.3 & -19.09 & -1.09 \\
\hline 8 & GARUT & 66916.4 & 49222.5 & -26.44 & -1.49 \\
\hline 9 & INDRAMAYU & 138867 & 140826 & 1.41 & 0.16 \\
\hline 10 & KARAWANG & 136803 & 123645 & -9.62 & -1.11 \\
\hline 11 & KOTA BANDUNG & 5774.45 & 1053.24 & -81.76 & -0.40 \\
\hline 12 & KOTA BANJAR & 3812.56 & 5122.86 & 34.37 & 0.11 \\
\hline 13 & KOTA BEKASI & 12037.1 & 2175.19 & -81.93 & -0.83 \\
\hline 14 & KOTA BOGOR & 6317.67 & 2278.52 & -63.93 & -0.34 \\
\hline 15 & KOTA CIMAHI & 1713.28 & 365.485 & -78.67 & -0.11 \\
\hline 16 & KOTA CIREBON & 2221.17 & 530.048 & -76.14 & -0.14 \\
\hline 17 & KOTA DEPOK & 12822.3 & 3867.88 & -69.83 & -0.75 \\
\hline 18 & KOTA SUKABUMI & 3737.02 & 2083.77 & -44.24 & -0.14 \\
\hline 19 & KOTA TASIKMALAYA & 9177 & 7888.48 & -14.04 & -0.11 \\
\hline 20 & KUNINGAN & 31357.6 & 18327.6 & -41.55 & -1.10 \\
\hline 21 & MAJALENGKA & 67731.9 & 55027.8 & -18.76 & -1.07 \\
\hline 22 & PANGANDARAN & 10536.1 & 15760.2 & 49.58 & 0.44 \\
\hline 23 & PURWAKARTA & 28314.7 & 16408.8 & -42.05 & -1.00 \\
\hline 24 & SUBANG & 114292 & 98959.6 & -13.42 & -1.29 \\
\hline 25 & SUKABUMI & 54811.3 & 59562.9 & 8.67 & 0.40 \\
\hline 26 & SUMEDANG & 43957.3 & 26527.6 & -39.65 & -1.47 \\
\hline \multirow[t]{2}{*}{27} & TASIKMALAYA & 22689.7 & 32202.5 & 41.93 & 0.80 \\
\hline & Jawa Barat & 1189729 & 983342.8 & -17.35 & \\
\hline
\end{tabular}

(data diolah)

Selain penurunan luas lahan yang disebabkan perubahan lahan sawah menjadi bukan sawah, di beberapa kabupaten/kota terjadi perubahan lahan dari bukan sawah ke lahan sawah seperti terlihat pada Gambar 8. Belum dapat dipastikan dengan jelas faktor bertambahnya luas sawah di beberapa kabupaen/kota. Beberapa hal yang mungkin terjadi diantaranya adalah adanya pembangunan saluran irigasi, penemuan varietas baru yang tahan penyakit dan cuaca ekstrem, gaya hidup masyarakat yang memilih beras organik, serta program pemerintah daerah dalam perluasan sawah baru (KEMENTAN, 2013). Perubahan lahan dari bukan sawah ke sawah terjadi pada bagian tengah dan selatan wilayah Provinsi Jawa Barat. 


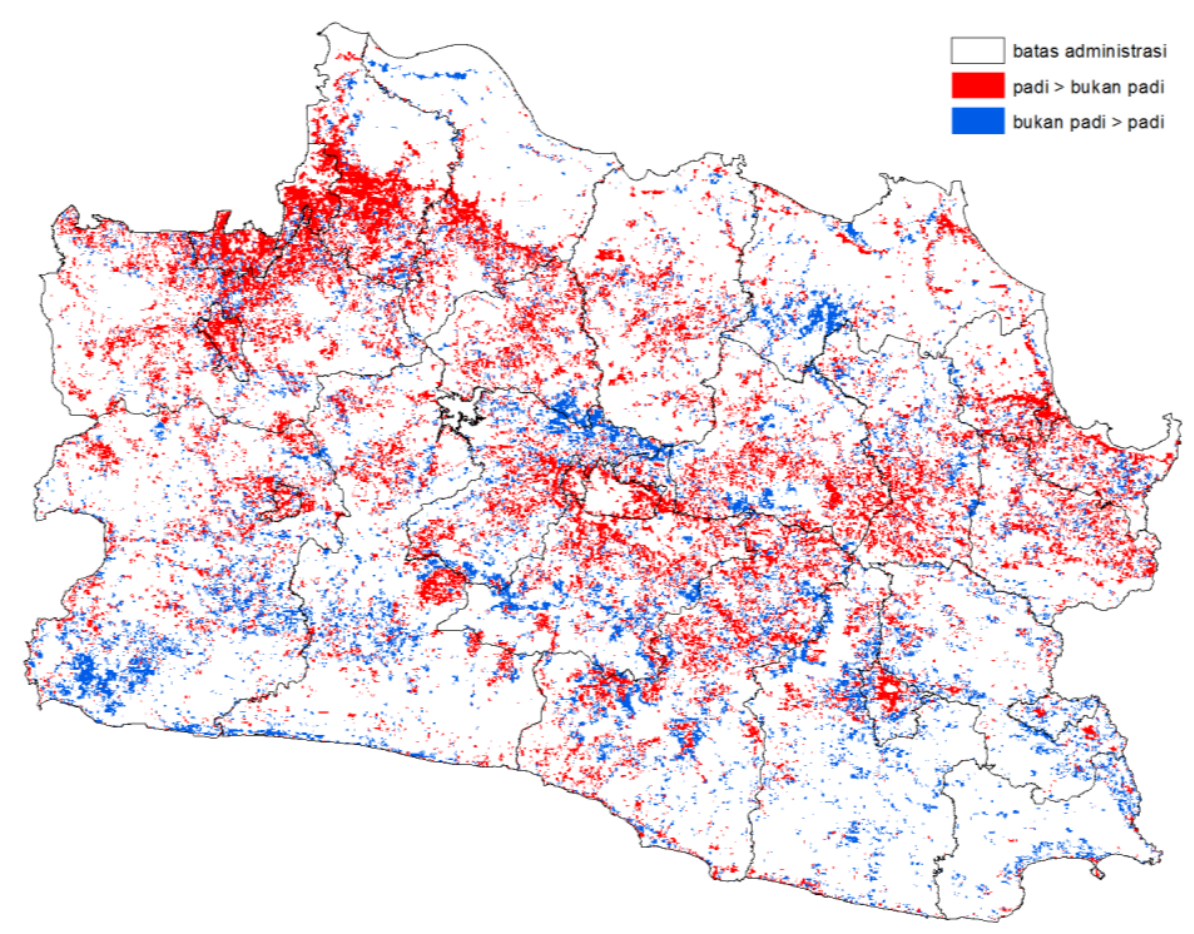

Gambar 8. Distribusi wilayah yang mengalami perubahan lahan dari sawah ke bukan sawah dan bukan sawah ke sawah

\section{Perbandingan Luas Lahan Sawah antara Citra MODIS dengan data BPS}

Luas sawah berdasarkan citra MODIS memiliki perbedaan yang sangat signifikan dengan luas sawah BPS (Gambar 9). Perbedaan ini kemungkinan besar terletak pada metode dan ketelitian yang berbeda dalam proses penentuan luas. Penentuan luas sawah citra MODIS ditentukan berdasarkan pengelompokan pola temporal piksel-piksel citra MODIS, kemudian dipilih piksel citra yang menyerupai pola temporal sawah. Sedangkan data BPS diperoleh melalui pengisian formulir statistik pertanian (Octora, 2014). Walaupun memiliki perbedaan dalam metode yang signifikan, kedua metode tersebut memiliki kesamaan kesimpulan bahwa telah terjadi penurunan luas sawah di Jawa Barat. Penurunan luas sawah ini perlu diperhatikan oleh pemerintah atau pihak terkait agar ketersediaan pangan tetap terjaga.

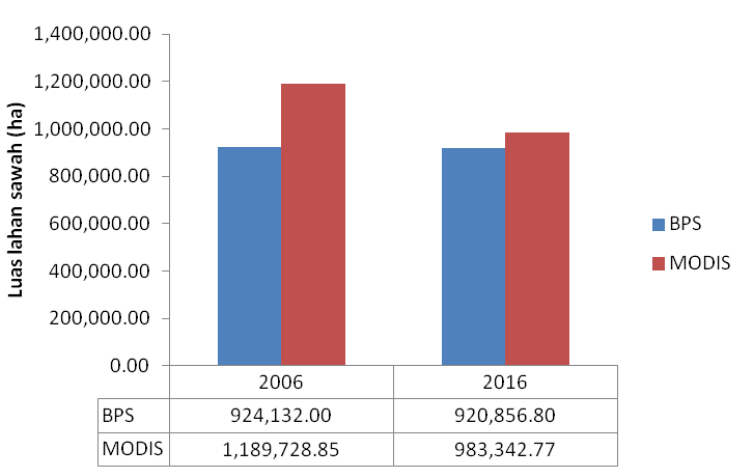

Gambar 9. Perbandingan luas lahan sawah antara data BPS dengan MODIS

Penurunan luas lahan sawah menurut citra MODIS lebih tinggi dibandingkan data BPS. Selama 10 tahun, luas sawah menurut citra MODIS menurun sebesar $17.35 \%$ sedangkan menurut data BPS penurunan hanya sebesar 0.35\%. Perbedaan yang cukup besar kemungkinan dapat terjadi karena metode yang diguakan, namun dalam metode pengolahan citra sendiri dapat juga disebabkan 
oleh adanya heterogenitas spasial, terutama dalam citra beresolusi menengah hingga kasar. Citra MODIS yang digunaka memiliki ketelitian $250 \mathrm{~m} \times 250 \mathrm{~m}$ atau setara dengan 6.25 ha. Menurut Shofiyati (2010), heterogenitas spasial merupakan tingkat akurasi data yang rendah disebabkan oleh informasi yang terekam dalam satu piksel citra lebih luas dibandingkan dengan luas lahan yang sebenarnya.

\section{KESIMPULAN DAN SARAN}

\section{Kesimpulan}

Klasifikasi tidak terbimbing ISODATA dapat dilakukan terhadap citra MODIS EVI untuk mengetahui luas dan sebaran lahan sawah secara regional khususnya Provinsi Jawa Barat. Luas sawah di Jawa Barat berdasarkan citra MODIS mengalami penurunan sebesar 17.35\%, dari 1,189,728.85 ha pada tahun 2006 menjadi 983,342.77 ha pada tahun 2016. Perubahan lahan sawah yang terjadi adalah perubahan lahan sawah menjadi lahan bukan sawah (terbesar terjadi di Kabupaten Bogor dan Bekasi) dan perubahan lahan bukan sawah menjadi lahan sawah (bagian tengah dan selatan Jawa Barat). Terdapat perbedaan luas sawah antara data BPS dengan citra MODIS yang disebabkan oleh metode yang berbeda,namun hal ini tetap menunjukkan kecenderungan yang sama. Informasi mengenai perubahan lahan yang dihasilkan dari klasifikasi citra MODIS selanjutnya dapat digunakan sebagai pendukung dalam pengambilan keputusan khususnya dalam perencanaan pertanian.

\section{Saran}

- Diperlukan kajian lebih lanjut terkait perubahan lahan sawah dan kaitannya dengan kondisi cuaca dan iklim selama tahun kajian
- Diperlukan dukungan data lapang yang lebih besar untuk memperkuat hasil analisis klasifikasi

\section{UCAPAN TERIMA KASIH}

Terima kasih disampaikan kepada Direktorat Riset, Pengabdian Masyarakat dan Inovasi (DRPMI) Universitas Padjadjaran yang telah memberi biaya penelitian melalui skema Riset Bidang Pemula Unpad (RDPU).

\section{DAFTAR PUSTAKA}

Amjad, A., 2009. Comparison of Strengths and Weaknesses of NDVI and LandscapeEcological Mapping Techniques for Developing an Integrated Land Use Mapping Approach. [Thesis]. International Institute for Geoinformation Science and Earth Observation, ITC, Enshede.

Arsyad, A., Rustiadi, E., 2008. Penyelamatan Tanah, Air, dan Lingkungan. Yayasan Obor Indonesia, Jakarta.

Bahar, Y., 2012. Rice Crop Monitoring System based on Modelling Approach. [Thesis]. Bogor Agricultural University, Bogor.

BPS, 2016. Provinsi Jawa Barat Dalam Angka 2016. BPS Jawa Barat, Bandung.

BPS, 2015. Jawa Barat Dalam Angka 2015. Badan Pusat Statistik, Bandung.

BPS, 2013. Jawa Barat Dalam Angka 2013. Badan Pusat Statistik, Bandung.

BPS, 2011. Jawa Barat Dalam Angka 2011. Badan Pusat Statistik, Bandung.

BPS, 2009. Jawa Barat Dalam Angka 2009. Badan Pusat Statistik, Bandung.

Huete, A.R., Liu, H.Q., Batchily, K., van Leeuwen, W., 1997. A comparison of vegetation indices over a global set of TM images for EOS-MODIS. Remote Sens. Environ. 59, 440-451. doi:10.1016/S00344257(96)00112-5 
Jaya, I.N.S., 2010. Analisis Citra Digital, 2nd ed. Fakultas Kehutanan, IPB, Bogor.

KEMENTAN, 2013. Buku Cetak Sawah Indonesia. Kementrian Pertanian, Jakarta.

Noer, M., 2008. Estimasi produksi tanaman padi sawah di Kabupaten Bekasi, Karawang, dan Subang. [Thesis]. Universitas Indonesia, Depok.

Octora, W., 2014. Analisis Luas Lahan Sawah Berbasis Citra MODIS di Provinsi Jawa Barat Tahun 2002-2012. [Skripsi]. IPB. Bogor.

Permatasari, P.A., Fatikhunnada, A., Liyantono, Setiawan, Y., Syartinilia, Nurdiana, A., 2016. Analysis of Agricultural Land Use Changes in Jombang Regency, East Java, Indonesia Using BFAST Method. Procedia Environ. Sci. 33, 27-35. doi:10.1016/j.proenv.2016.03.053

PUSDATIN, 2015. Statistik Data Lahan 2015. Kementrian Pertanian, Jakarta.

Sampurno, R.M., Seminar K.B., Suharnoto Y., Weed Control Decision Support System Based on Pecision Agriculture Approach. TELKOMNIKA (Telecommunication, Computing, Electronics and Control). 12(2): 475.

Sampurno, R.M., Thoriq, A., 2016. Klasifikasi Tutupan Lahan Menggunakan Citra Landsat 8 Operational Land Imager (OLI) Di Kabupaten Sumedang. TEKNOTAN $10.2,62-71$.
Semedi, J.M., 2012. Rice Crop Spatial Distribution and Production Estimation using Modis EVI (Case Study of Karawang, Subang, and Indramayu Regency). Bogor Agricultural University.

Setiawan, Y., Liyantono, Fatikhunnada, A., Permatasari, P.A., Aulia, M.R., 2016. Dynamics Pattern Analysis of Paddy Fields in Indonesia for Developing a Near Real-time Monitoring System Using MODIS Satellite Images. Procedia Environ. Sci. 33, 108-116. doi:10.1016/j.proenv.2016.03.062

Setiawan, Y., Yoshino, K., 2014. Detecting landuse change from seasonal vegetation dynamics on regional scale with MODIS EVI 250-m time-series imagery. J. Land Use Sci. 9, 304-330. doi:10.1080/1747423X.2013.786151

Setiawan, Y., Yoshino, K., Philpot, W.D., 2013. Characterizing temporal vegetation dynamics of land use in regional scale of Java Island, Indonesia. J. Land Use Sci. 8, $1-30$.

doi:10.1080/1747423X.2011.605178

Shofiyati R., 2010. Integrasi multi resolusi citra satelit dengan metode sederhana untuk memonitor kondisi lahan. J. Inform. Pertan. 19, 109-124. 